\title{
The Variscan belt: correlations and plate dynamics
}

\author{
Pavel Pitra ${ }^{1,2} \cdot$ Karel Schulmann ${ }^{2,3}$ • José Ramón Martínez Catalán ${ }^{4}$. \\ Michel Ballèvre ${ }^{1}$
}

Published online: 16 February 2017

(C) Springer-Verlag Berlin Heidelberg 2017

The new series of international conferences focused on the Palaeozoic evolution of the European lithosphere started in 2007 in Orléans, followed by the successful meeting in 2012 in Sassari, and the last one in 2015 in Rennes. The first conference was dedicated to mechanical aspects of the Variscan orogeny and resulted in a highly successful Special Issue of Comptes Rendus Geoscience published in 2009. The second, Sassari conference was devoted to the extent and time scales of formation of the European crust and resulted in a number of excellent papers published in the form of a Special Publication of the Geological Society of London (\# 405, 2014). The last, Rennes conference, was dedicated to the correlations and plate dynamics across the European Variscan belt and resulted in the current special issue of the International Journal of Earth Sciences. The papers published in this volume clearly show that the Variscan orogenic research evolves to become more modern and quantitative based in particular on detailed stateof-the-art geochronology and geochemistry, and the advent of numerical modelling. The community is critically using large and new data sets of high-resolution geochronological data combined with modern geochemistry and

Pavel Pitra

pavel.pitra@univ-rennes1.fr

1 Géosciences Rennes, UMR CNRS 6118, Université Rennes 1, Campus de Beaulieu - bât. 15, 35042 Rennes cedex, France

2 Centrum výzkumu litosféry, Česká geologická služba, Klárov 3, 11821 Praha 1, Czech Republic

3 Université de Strasbourg, EOST, UMR 7517, 1 Rue Blessig, 67084 Strasbourg, France

4 Departamento de Geología, Facultad de Ciencias, Universidad de Salamanca, 37008 Salamanca, Spain an increasing volume of high-quality information from metamorphic petrology and structural geology. It becomes obvious that the evolution of the European Variscan belt is diachronous in various senses. As an example, the main paroxysmal event, characterised by the HT-LP metamorphism and associated granitic magmatism, culminated at $\mathrm{c}$. $340 \mathrm{Ma}$ in the north-east and c. 320-300 Ma to the southwest. A new geodynamic scenario emerges that takes into account the important Ordovician extensional event, and the mid-Ordovician Sardic unconformity in various regions of the belt as well as more precise data of igneous events coming from northern Gondwana and southern Laurussia. Altogether, new results show that the progress in Variscan orogenic research is converging towards a new paradigm involving more precise plate configurations and dynamics in Palaeozoic times. This volume of the International Journal of Earth Sciences is an evidence of this tendency and presents several studies documenting the fundamental importance of detailed geochronology, coupled with solid geological field data, for unravelling the complex geological history of the Variscan belt.

Racek et al. use a novel approach to decipher the polyphase Variscan kinematics on the eastern margin of the Bohemian massif via kinematic modelling coupled with detailed Ar/Ar geochronology. They demonstrate the frontal character of the thrusting of the Moldanubian hot nappe over the easterly Brunia basement. The hornblende Ar/Ar data, yielding two peaks at c. 342 and $332 \mathrm{Ma}$, document the associated progressive erosion of the nappe during the thrusting and are correlated with published Ar/Ar ages on detrital muscovite from the adjacent foreland basement.

Laurent et al. propose an impressive data set of geochronological and geochemical data on various types of both granitoid and mafic rocks from the eastern French Massif Central. They document that all these magmatic rocks 
emplaced together over a long period of $\sim 40$ million years throughout the Carboniferous (c. 340-300 Ma). The coeval melting of both crustal and mantle sources during this long-lived magmatic episode possibly resulted from a lithospheric-scale thermal anomaly, triggered by the removal of the lithospheric mantle root. The spatial distribution of the dated samples points to a progressive southward delamination of the lithospheric mantle.

Two papers are dedicated to detailed U-Th-Pb LA-ICPMS geochronology of the famous Montagne Noire complex (southern French Massif Central). Trap et al. argue for a prolonged period of partial melting, associated with the emplacement of syntectonic granites, lasting from c. 315 to c. $300 \mathrm{Ma}$, and contemporaneous with D2 transpressional and D3 extensional deformations. These two deformations are interpreted to have been synchronous, but spatially partitioned within the crust.

On the other hand, Poujol et al. focus on a detailed geochronological analysis of a migmatite and an associated anatectic granite and argue that partial melting occurred in two distinct stages (at c. 320 and c. $300 \mathrm{Ma}$ ). This is used as an argument in favour of the extensional character of the Montagne Noire dome. Furthermore, with respect to existing age data, Poujol et al. document that careless statistical treatment of chemical (microprobe) monazite data may be at the origin of spurious geochronological results. This is an important general message, since a large number of such data are published and should be dealt with extreme caution in regional syntheses or large-scale tectonic interpretations.

Similarly, Lotout et al. show that porphyritic granites in the Lévézou complex (southern French Massif Central), straddling the contact between the Lower Allochthon and the eclogite-bearing Upper Allochthon, are of Ordovician age (c. $470 \mathrm{Ma}$ ). Their geochemical and isotopic nature links them to a major magmatic Ordovician event recorded throughout the European Variscan belt and related to extreme thinning of continental margins during a rifting event or a back arc extension. Previously, these granites were erroneously interpreted as intrusions syntectonic with a Late Devonian-Early Carboniferous thrusting, based on misinterpreted geochronological data and structural observations. The new findings call for revision of the existing tectonic interpretation of this part of the French Massif Central.

An inspiring unconventional view of the geodynamic setting of the pre-Variscan, Ordovician period is proposed by Zurbriggen, based on examples from the pre-Variscan basement of the Alps. It is argued that following the Pan-African assembly of Gondwana, this continent was bounded by several $100 \mathrm{~km}$ wide cratonized subductionaccretion complexes (SACs), a unique orogenic type termed the Cenerian orogeny. This resulted in the formation of specific rock sequences composed of metagreywackes and metapelites with intercalated amphibolites and sheets of Cambro-Ordovician peraluminous metagranitoids. The central role of recycling Proterozoic continental crust by the cratonization of SACs at the periphery of Gondwana in the formation of Proto-European continental crust is highlighted.

Franceschelli et al. study the classic early Ordovician Sardic unconformity in the Iglesiente region in Sardinia. They document the various pre-Variscan and Variscan deformation events. Using a detailed petrological approach, they show that there is no significant difference in the $\mathrm{P}-\mathrm{T}$ metamorphic conditions between the rocks underlying and overlying this angular unconformity.

The structural analysis of Dias et al. shows that the widespread NNE-SSW sinistral strike slip faults in western Iberia may be Late Variscan second-order domino structures related to first-order E-W dextral shears, linked to the dextral oblique collision between Laurentia and Gondwana during Late Carboniferous-Permian times.

Finally, the contribution of Okay and Topuz is an instructive overview, based on precise geochronological data, of the Variscan history of two Gondwana-derived Palaeozoic belts that rim the south of the Archaean-Palaeoproterozoic Ukrainian shield in the Black Sea region. The northern belt comprises Palaeozoic passive-margin-type sedimentary rocks, whereas the southern belt is dominated by granites (335-294 Ma) and HT-LP metamorphic rocks. They are interpreted to represent, respectively, the southfacing continental margin of the Laurussia, and a continental magmatic arc, which collided with the southern margin of Laurussia during the Early-Late Carboniferous boundary. It is argued that in the Black Sea region, there was no terminal collision of Laurussia with Gondwana during the Late Palaeozoic and the Laurussia margin continued to face the Palaeo-Tethyan ocean in the south. 